\title{
Kehidupan Toleransi Beragama Disekolah
}

\author{
Meliati Ake \\ Jurusan PG-PAUD Universitas Negeri Gorontalo \\ meliatiake@gmail.com
}

\begin{tabular}{l}
\hline Info Artikel \\
\hline Sejarah Artikel: \\
Diterima (April) (2019) \\
Disetujui (Mei) (2019) \\
Dipublikasikan (Juli) (2019) \\
\hline Keywords: \\
Life, Religious, \\
Tolerance, Early \\
Childhood \\
\hline
\end{tabular}

\begin{abstract}
Abstrak
Penelitian ini di buat dari hasil penelitian kehidupan toleransi Beragama disekolah yang mendasar pada judul dan pembahasan mengenai toleransi beragama disekolah melalui aspek perkembangan nilai agama dan moral yang nanti akan diterapkan dalam sistem perkembangan anak. Tujuan dari penelitian ini adalah agar para guru di sekolah dapat menerapkan sikap toleransi terhadap anak di sekolah sesuai dengan keyakinan beragama anak. Metode yang di gunakan dalam penelitian ini adalah metode penelitian kualitatif. Penelitian kualitatif ialah mendeskripsikan hasil pengamatan dalam suatu objek. Upaya yang dilakukan guru dalam menanamkan sikap toleransi dalam kehidupan sekolah yaitu dengan memberikan pelatihan kepada anak untuk melihat bagaimana perbedaan diantara mereka. Pada dasarnya anakanak melakukan hal yang sama tanpa ada sikap toleransi. Upaya penanaman sikap toleransi ini sudah menjadi kebijakan sekolah untuk menjauhkan anakanak dari sikap tidak saling menghargai atau intoleran
\end{abstract}

\begin{abstract}
This research was made from the result of a study of religious tolerance in school through aspects of the development of religious and moral values which will later be applied in the child development system. The purpose of this study is that school in children at school in accordance with children's religious beliefs. The method used in this study is a qualitative research method. Qualitative research is to describe the results of observations in an object. The efforts made by teachers in instilling tolerance in school life are by giving training to children to see how they differ. Basically, children do the same thing without tolerance have become school policies to keep children away from mutual disrespect or intolerance.
\end{abstract}

Pendahuluan

Dalam era globalisasi, orang tua atau pendidik dituntut untuk menyadari bahwa sumber nilai-nilai agama dan moral yang di upayakan kepada anaknya perlu disandarkan kepada sumber nilai yang memiliki kebenaran mutlak. Hal ini dapat memberikan "kompas" kepada anak untuk mengarungi dunia dengan perubahan yang 
sangat cepat sehingga tidak larut didalamnya. Disamping itu, untuk memberikan kepastian pada anak agar berperilaku yang jelas arahnya untuk waktu yang tidak terhingga.

Bagi anak yang telah memiliki nilai-nilai agama dan moral yang sandaran nilainya berasal dari agama. tanpa kehadiran orang tua pun nilai-nilai itu tetap direalisasikan. Perelisasiannya mereka rasakan sebagai kewajiban dan mereka senantiasamerasa dipantau dan beraduensi dengan yang maha segalanya. Dengan demikian, apresiasi diri mereka (anak-anak) terhadap nilai-nilai agama tidak harus hanya dimaknai secara imanensi-transendental, tetapi juga bermakna secara ekumenitransedental (dalam kerangka hubungan sesame manusia keluarga. Dan diri dengan sendiri) Temuan penelitian menyatakan bahwa tanggapan diri anak dalam menyikapi nilai-nilai agama (nyaris tidak shalat, mengaji, puasa, dan shalat pada hari raya serta berani terhadap orang tua) merupakan realisasi kepemilikannya terhadap nilai agama yang di apresiasi secara naluri.

Bagi anak yang melakukan, pembenaran diridalam mengapresiasi nilai-nilai agama secara naluri menurutnya adalah hal yang wajar. Kewajaran ini setara dengan gelap dan pekatnya nilai-nilai agama dalam kehidupan keluarga dan diperparah oleh perilaku orang tua (orang tua laki-laki) yang sering melakukan penyimpangan.

Temuan penelitian menunjukkan bahwa anak-anak yang rajin shalat,mengaji, dan belajar patuh terhadap orang tua; menjaga kebersihan tempat suci; keharmonisan, kedekatan, keintiman, dan keakraban dalam hubungan sosial; hidup ekonomis, bersih, dan teratur; serta menempatkan segala sesuatu pada tempatnya yang dirasakan sebagai suatu penunaian kewajiban diri, merupakan bentuk apresiasi dirinya terhadap nilai agama berdasarkan kata hati. Menurut KBBI (Depdiknas, 2008:326) kata pendidikan berasal dari kata "didik" dengan memperoleh imbuhan "pe" serta "an", yang artinya langkah, sistem atau perbuatan mendidik. Pendidikan adalah proses perubahan sikap dan tata laku seseorang atau kelompok orang dalam usaha mendewasakan manusia melalui upaya pengajaran dan pelatihan. Maka dapat dikatakan pendidikan adalah suatu sistem pengubahan sikap serta perilaku seorang atau kelompok dalam usaha mendewasakan manusia atau peserta didik lewat usaha pengajaran serta kersus. 
Menurut Dewantara (1997) pendidikan adalah tuntutan di dalam hidup Tumbuhnya anak-anak, adapun maksudnya, pendidikan yaitu menuntun segala kekuatan kodrat yang ada pada anak-anak itu, agar mereka sebagai manusia dan sebagai anggota masyarakat dapatlah mencapai keselamatan dan kebahagiaan setinggitingginya.

Berdasarkan Hasil penelitian pada TK Aghatis Kecamatan Dengilo Kabupaten Pohuwato Provinsi Gorontalo. Pada dasarnya anak-anak melakukan hal yang sama tanpa ada sikap toleransi. Misalnyasetiap anak yang akan berdoa masuk kelas atau berdoa makan guru tidak memberitahukan doa sesuai dengan agama masing-masing tetapi dalam hal ini guru masih tetap menyatukan anak dalam sekelas untuk berdoa sama-sama padahal menurut peneliti anak-anak bisa saja di pisahkan atau berdoa sesuai dengan keyakinan masing-masing.

Tujuan dari penelitian ini yaitu agar para guru di sekolah dapat menerapkan sikap toleransi terhadap anak di sekolah sesuai dengan keyakinan beragama anak. Dan artikel yang ini juga dibuat untuk memberikan kesadaran terhadap lingkungan masyarakat untuk lebih menrapkan sikap toleransi terhadap diri masing-masing.

Awal permasalahan yang peneliti temui dalam sekolah ini yaitu tidak adanya sikap dan kehidupan toleransi antar beragama disekolah. Menurut Sarwono (2010:201), sikap (attitude) adalah istilah yang mencerminkan rasa senang, tidak senang atau perasaan biasa-biasa saja (netral) dari seseorang terhadap sesuatu. Sesuatu itu bisa benda, kejadian, situasi, orang-orang atau kelompok. Apabila yang timbul terhadap sesuatu itu adalah perasaan senang, maka disebut sikap positif, sedangkan apabilasesuatu itu adalah perasaan tak senang, maka disebut sikap negatif. Apabila timbul perasaan apa-apa, berarti sikapnya netral.

Menurut Kamus Besar Bahasa Indonesia (Depdiknas, 2008:1447-1448), toleransi berasal dari kata "toleran" yang berarti bersifat atau bersikap menenggang (mengharga, membiarkan, membolehkan), pendirian (pendapat, pandangan, kepercayaan, kebiasaan dan sebagainya) yang berbeda dan atau yang bertentangan dengan pendiriannya. Toleransi juga berarti batas ukur untuk penambahan atau pengurangan yang masih diperbolehkan. Secara bahasa atau etimologi (Munawir, 
t.th:1098) toleransi berasal dari bahasa arab yakni "tasamuh" yang artinya ampun, maaf dan lapang dada.

Menurut (Hasyim 1979:22) toleransi yaitu pemberian kebebasan kepada sesama manusia atau kepada sesama warga masyrakat untuk menjalankan keyakinan atau mengatur hidupnya dan menentukan nasibnya masing-masing, selama dalam menjalankan keyakina atau mengatur hidupnya dan menentukan nasibnya masingmasing, selama dalam menjalankan dan menentukan sikapnya itu tidak melanggar dan tidak bertentangan dengan syarat-syarat atas terciptanya ketertiban dan perdamaian dalam perdamaian dalam masyarakat.

Pendapat lain di kemukakan oleh (Poerdarminto 1986:184) dalam kamus umum bahasa indonesia, toleransi adalah sikap atau sifat menenggang berupa menghargai serta memperbolehkan suatu pendirian, pendapat, pandangan, kepercayaan maupun yang lainnya yang berbeda dengan pendirian sendiri.

Dari beberapa definisi di atas peneliti dapat menyimpulkan bahwa toleransi adalah suatu sikap atau sifat untuk membiarkan kebebasan terhadap orang lain serta memberikan kebenaran dan ketenaran atas perbedaan tersebut. Toleransi merupakan sikap atau sifat yang sudah menghiasi hati manusia tanpa terkecuali, sehingga memudahkan orang lain untuk saling berinteraksi dan menghargai segala bentuk perbedaan sikap toleransi ini dapat mempermudah jalan untuk menjalin tali silaturahmi dan memepererat tali persaudaraan. Karena saling menghargai antar agama terhadap kebhinekaan (pluralitas) yang mengedepankan aspek nilai agama dan moral agar dapat terbentuknya masyarakat yang majemuk.

\section{Metode Penelitian}

Jenis Penelitian

Metode penelitian yang digunakan dalam membuat artikel ini adalah metode kualitatif. Istilah penelitian kualitatif menurut Krik dan Miller (dalam Nasution, 1988:23) pada mulanya bersumber pada pengamatan kualitatif yang dipertentangkan dengan pengamatan kuantitatif. lalu mereka mendefinisikan bahwa metodologi kualitatif adalah tradisi tertentu dalam ilmu pengetahuan sosial yang secara fundamental bergantung pada pengamatan pada manusia dalam kawasannya sendiri dan berhubungan dengan orang-orang tersebut dalam peristilahannya. 
Menurut Strauss dan corbin dalam Cresswell, J. (1998:24), yang di maksud dengan penelitian kualitatif adalah jenis penelitian yang menghasilkan penemuanpenemuan yang tidak dapat dicapai (diperoleh) dengan menggunakan prosedurprosedur statistik atau cara-cara lain dari kuantifikasi (pengukuran).

Metode penelitian kualitatif ini Kegagalan adalah kesuksesan yang tertunda dan kebohongan adalah kejujuran yang tertundagunakan untuk mendapatkan data yang maksimal metode ini dapat digunakan untuk menjabarkan berbagai data yang telah di teliti. Bodgan dan Biklen, S. (1993:21-22) menjelaskan bahwa penelitian kualitatif adalah salah satu prosedur penelitian yang menghasilkan data deskriptif berupa ucapan atau tulisan dan perilaku orang yang diamati. pendekatan kualitatif diharapkan mampu mrnghasilkan uraianyang mendalam tentang ucapan, tulisan,dn atau perilaku yang dapat diamati dari suatu individu, kelompok, masyarakat, dan atau organisasi tertentu dalam suatu setting konteks tertentu yang dikaji dari sudut pandang yang utuh, komprehensif, dan holistik. penenelitian kualitatif bertujuan untuk mendapatkan pemahaman yang sifatnya umum terhadap kenyataan sosial dariperspektif partisipan.

Waktu dan Tempat Penelitian

Penelitian ini di laksanakan di TK Agathis Kecamatan Dengilo Kabupaten Pohuwato Provinsi Gorontalo. Penelitian ini dilaksanakan pada bulan Oktober 2019 SampaiNovember 2019.

\section{Subjek Penelitian}

Subjek penelitian ini merupakan orang yang dituju untuk diteliti oleh peneliti. Dalam penentuan subjek ini peneliti menentukan guru dan kepala sekolah untuk di teliti serta siswa. Peneliti melihat ada beberapa orang siswa dan guru yakni 10 orang siswa perempuan dan 11 orang siswa laki-laki. Tenaga pendidik di TK Aghatis ada 3 orang yakni 1 orang kepala sekolah dan 2 orang pendidik (guru).

Data, Intrumen, dan Teknik Pengumpulan Data

Pengumpulan data penelitian ini menggunakan metode observasi danInstrumen pertama yaitu peneliti sendiri. Peneliti menggunakan metode observasi untuk mengumpulkan berbagai data untuk hasil yang maksimal. 
Penelitian ini bertujuan untuk mengungkap dan menanamkan sikap toleransi kepada anak di TK Agathis Kecamatan Dengilo Kabupaten Pohuwato. proses analisis data dilakukan selama penelitian dilapangan. Analisis data yang digunakan selama dilapangan yaitu penyajian data dan kesimpulan.

\section{Hasil Penelitian dan Diskusi}

Berdasarkan hasil wawancara dan observasi peneliti menemukan bahwa upaya yang dilakukan kepada guru dan kepala sekolah dalam menanamkan sikap toleransi ialah melalui kebijakan sekolah. Hal ini sesuai dengan pendapat Kemendiknas (2010:19) yang mengemukakan bahwa budaya sekolah memiliki cakupan yang luas, meliputi ritual, harapan, hubungan, demografi, kegiatan kurikuler, kegiatan ekstrakurikuler, proses pengambilan keputusan, kebijakan maupun interaksi sosial antar komponen di sekolah.

Budaya sekolah merupakan susana kehidupan sekolah dimana siswa dan para guru berinteraksi dengan sesama. Para guru dan orang tua menjadi faktor utama pendidikan bagi anak di sekolah. Interaksi ini dapat terikat oleh berbagai aturan, misalnya norma, moral,agama dan etika bersama yang berlaku dalam lingkungan sekolah. Hal tersebut menunjukkan bahwa kebijakan dan sikap saling menghargai ada dalam para guru anak dan orang tua. Sekolah merupakan salah satu tempat dimana anak dapat mengembangkan budaya dan sikap toleransi yang tinggi antar sesama manusia.

Selain itu, upaya lain yang dilakukan guru dalam mengembangkan/menerapkan kehidupan bertoleransi kepada anak di sekolah yaitu guru memberikan kegiatan rutin yakni kajian-kajian tentang ilmu agama atau keyakinan yang dianut siswa itu sendiri. Selain itu kegiatan guru dalam menerapkan sikap toleransi kepada anak dengan menggunakan metode bermain, agar anak bisa saling menghargai sesama. kegiatan rutin juga dilakukan dalam sekolah seperti Berdoa menurut agama dan keyakinan masing-masing. Sebelum anak mengetahui keyakinan mereka, para guru melakukan kegiatan rutin seperti yang telah di jabarkan sebelumnya, disini guru sangat berperan penting dalam penanaman sikap toleransi kepada anak. Dalam kegiatan rutin para guru membiasakan anak untuk bersalaman sebelum masuk kelas atau berjumpa dengan guru lain di sekolah, anak juga di biasakan untuk bersalaman sebelum pulang ke rumah bersama orang tua. Hal ini sesuai dengan Pendapat (Ahmadi 1999:178) yang 
mengemukakan bahwa slah satu ciri sikap yaitu memiliki kestabilan. Sikap bermula dari dipelajari, kemudian menjadi lebih kuat, tetap dan stabil. Begitu juga dengan sikap toleransi yang dibiasakan melalui kegiatan rutin. melalui kegiatan rutin ini siswa dibiasakan untuk belajar sikap bertoleransi antar sesama. Lama-kelamaan anak mulai menerapkan sikap toleransinya kepada teman, guru dan orang tua. Kegiatan rutin yang dilakukan oleh para guru bertujuan untuk memberikan kestabilan dalam kehidupan bertoleransi di sekolah.

Selanjunya, upaya penanaman sikap toleransi ini dilakukan melalui keteladanan dengan cara memberikan sikap toleransi terhadap siswa agar di terapkan dalam kehidupan sehari-hari. Hal tersebut sesuai dengan pendapat (Borba 2008:13) yang mengemukakan pentingnya keteladanan yang dalam penjelasannya lebih menunjuk pada bagaimana membantu anak atau siswa dalam "menangkap" keajikan pembangunan kecerdasan moral. Pernyataan ini selaras apabila dikaitkan dengan keteladanan dalam upaya penanaman sikap toleransi. Michele Borba menyatakan bahwa mengajarkan kebajikan kepada anak tidak sama pengaruhnya dibandingkan menunjukkan kualitas kebajikan tersebutdalam kehidupan. mengulangi lagi kesalahannya di kemudian hari.

Upaya lain yang dilakukan guru dalam menanamkan sikap toleransi dalam kehidupan sekolah yaitu dengan memberikan pelatihan kepada anak untuk melihat bagaimana perbedaan diantara mereka. Dengan diterapkannya hal tersebut anak dapat menghargai perbedaan yang ada di antara mereka. Selain itu guru memberikan pengarahan kepada anak untuk menghargai perbedaan potensi yang dimilikinya. Hal ini sesuai dengan pendapat Michele Borba (2008:247) yang menyatakan bahwa perbedaan itu bukanlah masalah. Perbedaan bukanlah jurang pemisah antara satu orang dengan orang lain, justru dengan perbedaan dunia akan terasa lebih indah. Dengan adanya perbedaan anak dapat mengenal keberagaman yang ada di antara mereka.

Kegiatan pembelajaran yang dilakukan guru dalam menerapkan sikap toleransi kepada anak yaitu dengan membentuk kelompok diskusiuntuk memecahkan berbagai masalah yang berkaitan dengan materi atau topik pembelajaran,dengan tujuan agar anak saling menghargai orng lain pada saat pembelajaran berlangsung. Hal ini sesuai dengan pendapat Kemendiknas (2010:18) yang menyatakan bahwa salah satu cara 
menanamkan sikap toleransi kepadapara siswa ialah melalui pengintegrasian kedalam mata pelajaran. Dengan adanya pengintegrasian kedalam mata pelajaran, penanaman sikap toleransi bisa langsung ditanamkan kepada siswa tanpa harus membuat sesi tersendiri untuk program penanaman sikap toleransi.

Dalam penanaman nilai kehidupan bertoleransi disekolah guru dapat menerapkannya dengan menggunakan metode belajar sambil bermain di dalam kelas dengan tujuan agar anak dapat lebih saling menghargai sesama dan menumbuhkan rasa solidaritas yang tinggi kepada anak. Dengan demikian, diharapkan kepada para guru untuk tetap mempertahankan apa yang telah di capai saat ini melalui pengintegrasian penanaman sikap toleransi yang tinggi terhadap anak dan berlatih untuk menghargai orang lain melalui berbagai program pembelajaran yang ada di sekolah.

\section{Simpulan}

Berdasarkan uraian diatas dapat diambil kesimpulan bahwa TK Agathis telah melakukan upaya penanaman sikap toleransi kepada para siswa. Upaya penanaman sikap toleransi ini sudah menjadi kebijakan sekolah untuk menjauhkan anak-anak dari sikap tidak saling menghargai atau intoleran. Upaya guru dalam menjalankan kegiatan rutin untuk menanamkan sikp toleransi kepada anak akhirnya berjalan dengan baik tanpa kendala, sikap toleransi ini sangat baik untuk diterapkan dalam kehidupan beragama di sekolah, karena anak bisa mengetahui bagaimana menghargai orang lain walaupun dengan keyakinan yang berbeda.

\section{Daftar Pustaka}

Shochib Dr. moh (1998). Pola Asuh Orang Tua. Cet. I.Jakarta Anggota IKAPI: PT. RINEKA CIPTA.

Sri Soryani (2015). Penanaman Sikap Toleransi. Journal.Student.Uny.ac.id

Muamanah (2018). Pentingnya Pendidikan Untuk Tanamkan Sikap Toleran Di Masyarakat. https://osf.id

Pupu SaefulRahmat. Penelitian Kualitatif. Yusuf.Staff.ub.ac.id 